\title{
DEMOGRAPHIC MONITORING AND FORECASTING TOURISTS' ARRIVALS AS A MEANS OF OVERCOMING SEASONALITY
}

\author{
Aleksandra VUJKO* \\ Novi Sad Business School, Vladimira Perića Valtera 4, 2100o, Novi Sad, Vojvodina, Serbia, \\ South Ural State University, Institute of Sports, Tourism and Service, \\ 76 Lenin Ave., Chelyabinsk 454080, Russia, e-mail: aleksandravujko@yahoo.com
}

\section{Tatiana N. TRETIAKOVA}

South Ural State University, Institute of Sports, Tourism and Service, 76 Lenin Ave., Chelyabinsk 454080, Russia, e-mail: ttn1@mail.ru

\section{Dragana DIMITRIĆ}

University of Novi Sad, Faculty of Geography, Tourism and Hotel Management, Trg Dositeja Obradovića 3, 21000 Novi Sad, Serbia, e-mail: sandranel@yahoo.com

\section{Marko D. PETROVIĆ}

Geographical Institute "Jovan Cvijič", Serbian Academy of Sciences and Arts (SASA), Djure Jakšića 9, 11000 Belgrade, Serbia; South Ural State University, Institute of Sports, Tourism and Service, 76 Lenin Ave., Chelyabinsk 454080, Russia, e-mail: m.petrovic@gi.sanu.ac.rs

\section{Milan RADOVANOVIĆ}

Geographical Institute “Jovan Cvijič”, Serbian Academy of Sciences and Arts (SASA), Djure Jakšica 9, 11000 Belgrade, Serbia; South Ural State University, Institute of Sports, Tourism and Service, 76 Lenin Ave., Chelyabinsk 454080, Russia, e-mail: m.radovanovic@gi.sanu.ac.rs

\section{Darko VUKOVIĆ}

Geographical Institute "Jovan Cvijič", Serbian Academy of Sciences and Arts (SASA), Djure Jakšića 9,1100o Belgrade, Serbia; Department for Finance, St. Petersburg School of Economics and Management, National Research University Higher School of Economics, Kantemirovskaya ulitsa 3A, Office 331, Sankt Petersburg 194100, Russia, e-mail: vdarko@hotmail.rs

Citation: Vujko, A., Tretiakova, T. N., Dimitrić, D., Petrović, D. M., Radovanović, M., Vuković, D. (2018). DEMOGRAPHIC MONITORING AND FORECASTING TOURISTS' ARRIVALS AS A MEANS OF OVERCOMING SEASONALITY. GeoJournal of Tourism and Geosites. 22(2), 524534. https://doi.org/10.30892/gtg.22221-308

Abstract: Understanding the movement of tourists within a destination and
predicting future movements have their practical applications for destination
management, product development, marketing and attraction. We analyzed the
seasonality of tourist presence in Belgrade, using the ARIMA models, with the aim of
predicting future movement. We came to the result that about three-fourths of
tourists in this area consist of domestic tourists or residents of Belgrade and people
from other parts of Serbia, while the rest are foreign tourists. By increasing the

* Corresponding author 
number of foreign tourists there would be a significant economic development both for Ada Ciganlija Island and for Belgrade. This also points to the need for improving marketing and significantly engaging and making this area closer to foreign tourists.

Key words: Monitoring, Tourism, Ada Ciganlija Island, Belgrade, Serbia

\section{INTRODUCTION}

According to Papić-Blagojević et al. (2016), and Vujko et al. (2018), seasonality is one of the main aspects affecting tourism, and forecasts of tourist arrivals are essential for planning (Brougham \& Butler, 1981), policy making (Dogan, 1989; Canizares et al., 2016) and budgeting purposes by tourism operators (Choi \& Murray, 2010; Deng et al., 2011; Gounopoulos et al., 2012). Ada Ciganlija is a river island on Sava River and popular swimming area for residents of Belgrade during the summer, but it attracts a significant number of visitors off summer season, so, as such, it represents one of the favorite zones of picnic-recreational tourism within the city of Belgrade. Often do the residents of Belgrade call it "Belgrade Sea". Apart from providing certain facilities to Belgrade residents and domestic tourists, it is visited by the tourists from the region, as well as by quite a large number of foreign tourists.

Understanding the way tourists move through time and space (Turanligil \& Altintas, 2018), as well as the factors that influence their movements (Chen, 2000; Andereck et. al, 2007; Andereck \& Nyaupane, 2011; Ursache, 2015; Marković et. al, 2017), has important implications for infrastructure and transport development, product development, destination planning, and the planning of new attractions (Dwyer \& Kim, 2003; Dwyer et al., 2004), as well as management of the social, environmental, and cultural impacts of tourism (Lew \& McKercher, 2006; Petrović et al, 2016). However, the number of tourists, foreign tourist especially, and achieved economic and social effects of tourism, suggest that all these benefits are underused (Van Den Bergh, 1993; Lee \& Chang, 2008; Nunkoo \& Smith, 2013). Tourism may indicate the achievement of the objectives of development policy (Blake et al., 2006; Lee \& Chang, 2008; Sekaran \& Bougie, 2013), but it requires a continuous work and cooperation with state institutions (Vujko \& Gajić, 2014; Mhlanga et al., 2015; Sinclair-Maragh, 2017). There are assumptions that the intensive tourism development (all tourism products) in Ada Ciganlija may induce positive impact through a series of direct and indirect economic changes within certain categories not only in the area observed but also within the whole gravitating area, in this case, city of Belgrade. Our aim is to provide the empirical evidence that is the use of exponential smoothing model is useful for generating accurate prediction intervals, in practice. The autoregressive integrated moving average (ARIMA) model has excellent natural statistical characteristics and is the most popular (Sudheer \& Suseelatha, 2015). It has been found that there are preconditions to turn this area into a large-scale tourism development, and thus achieve visible economic effects.

\section{METHODOLOGY}

The research was conducted on monthly data relating to the number of tourists in Belgrade during the period from January 2000 to December 2015. The frequency of Belgrade series is platykurtic, which is confirmed both by the results of Jarque-Bera tests (Jarque \& Bera, 1987) and kurtosis. The time series show strong presence of seasonal 
Aleksandra VUJKO, Tatiana N. TRETIAKOVA, Dragana DIMITRIĆ, Marko D. PETROVIĆ, Milan RADOVANOVIĆ, Darko VUKOVIĆ

effect. Scaling factors of seasonal effects are calculated by applying multiplicative seasonal adjustment method, which means that factors represent ratios to moving average.

Tables 1. Basic statistics and scaling factors of seasonal effects for observed series Data source: The report of the Tourist Organization of Belgrade

\begin{tabular}{|l|l|l|l|}
\hline Mean & 56111.06 & 1 & 0.731681 \\
\hline Median & 56658 & 2 & 0.732539 \\
\hline Maximum & 86205 & 3 & 0.840048 \\
\hline Minimum & 27389 & 4 & 0.94708 \\
\hline Std. Dev. & 12102.68 & 5 & 1.121233 \\
\hline Skewness & -0.051611 & 6 & 1.097412 \\
\hline Kurtosis & 2.62769 & 7 & 1.270311 \\
\hline Jarque-Bera & 1.04489 & 8 & 1.29885 \\
\hline Probability & 0.593069 & 9 & 1.244596 \\
\hline Sum & 9426658 & 10 & 1.098282 \\
\hline Sum Sq. Dev. & $2.45 \mathrm{E}+10$ & 11 & 0.92941 \\
\hline Observations & 168 & 12 & 0.909228 \\
\hline
\end{tabular}

Unit root tests conducted on deseasonalized series, obtained by applying multiplicative seasonal adjustment method, show the evidence of non-stationarity in observed series. Therefore, all data were differenced, in order to obtain stationary series. To forecast the number of tourists in Belgrade, autoregressive moving average models (Whittle, 1951) were applied on transformed data:

$$
r_{t}=\phi_{0}+\sum_{i=1}^{p} \phi_{i} r_{t-i}-\sum_{j=1}^{q} \theta_{j} a_{t-j}+a_{t}
$$

Where $r_{t}$ is observed series, $\phi_{o}$ is constant, $\phi_{1}, \ldots, \phi_{p}$ and $\theta_{1}, \ldots, \theta_{p}$ are model parameters and $a_{t}$ is white noise. All series were tested with ARIMA $(1,1)$ to ARIMA $(5,5)$ models, and optimal models were selected based on Schwarz Bayesian information criterion (Schwarz, 1978):

$$
B I C=-2 \zeta+\frac{\log (T)}{T} k
$$

Where $\xi$ is $\log$ likelihood function, $T$ is sample size, and $k$ is number of parameters. Also, the statistical significance of parameters and autocorrelation of residuals were taken into the account. The specifications of selected models are given by Table 2. Analyses of observed series show strong evidence of seasonal effect, which was expected. Belgrade time series has the largest scaling factors during periods July August. This was the reason why we did some additional research.

The Tourist Organization of Belgrade had two clerks at the tourist information desk on the New Belgrade`s side of Ada Ciganlija, about a hundred and fifty feet away from the restaurant called "Lake", who were giving information to tourists interested in the city of Belgrade, informing them about the tourist destinations and tourist events, both in Belgrade and at Ada Ciganlija, as well. The tourist clerks have been noting down the number of tourists at the information desk and their interests. It was recorded that the visitors at the desk of the tourist information center, (hereafter called TIC), were the residents of Belgrade, domestic tourists and tourists from the region (from the former Yugoslav republics) and foreign tourists, likewise. However, because of the same-speaking 
region, a part of the tourists from the region or from the former republics merged into domestic tourists. The study was based on the main hypothesis H: that Ada Ciganlija, as recreational area, is attractive enough to attract tourists throughout the year, and that it is possible to determine the corrective measures and implement strategic actions for improving supply. This would further imply positive effects in the field of tourism and the general economy and the economy of the region. Under this hypothesis certain lowerlevel hypotheses were set: all the big cities having large picnic and recreational areas, and in this case it's Ada Ciganlija, enhance the landscape and it is their inhabitants that use these resources (hypothesis 1), the benefit of this landscaped area is multiple and particularly in the health domain (hypothesis 2), the native population uses picnic and recreational zone of their city more often than the foreign tourists (hypothesis 3 ).

\section{RESULTS AND DISCUSSION}

The examination of series forecast by ARIMA models showed that obtained forecasted values fitted historical data very well, which gives possibilities for prediction of future series values, as well as the examination of their mutual relationship and influence on economic indicators in observed regions.

Table 2. Selected ARIMA models for observed series Data source: The report of the Tourist Organization of Belgrade

\begin{tabular}{|l|l|l|l|}
\hline \multicolumn{1}{|c|}{ Variable } & \multicolumn{1}{|c|}{ Coef. } & Std. Err. & Prob. \\
\hline C & -41.417 & 133.873 & 0.758 \\
\hline AR (1) & \multicolumn{1}{c|}{1.629} & 0.028 & 0.000 \\
\hline AR (2) & -0.900 & 0.026 & 0.000 \\
\hline MA (1) & -2.188 & 0.080 & 0.000 \\
\hline MA (2) & 1.728 & 0.144 & 0.000 \\
\hline MA (3) & -0.429 & 0.080 & 0.000 \\
\hline R-sq & 0.304 & & \\
\hline Adj. R-sq & 0.281 & & \\
\hline S.E. of reg. & 4097.24 & & \\
\hline Sum sq. resid. & $2.60 E+09$ & & \\
\hline Log likelihood & -1564.60 & & \\
\hline F-stat & 13.54 & & \\
\hline Prob. (F-stat.) & 0 & & \\
\hline BIC & 19.63 & & \\
\hline Durbin-Watson & 1.96 & & \\
\hline Inv. AR Roots & $.81-.49 \mathrm{i}$ & $.81+.49 \mathrm{i}$ & \\
\hline Inv. MA Roots & $0.7 .86-43 \mathrm{i}$ & $.86-43 \mathrm{i}$ & 0.46 \\
\hline
\end{tabular}

The current tourist offer makes it possible for the local population (Chen \& Hsu, 2002; Zengeni \& Zengeni, 2012; Chibaya, 2013; Chingarande, 2014; Aliaskarov et al, 2017), to have access to landscaped zone that has a positive effect on their health (Allen et al., 1993), which enables Ada Ciganlija to be classified into another domain of tourism health tourism, and, hereby, hypothesis 1 and 2 are confirmed. Hypotheses No 2 is also confirmed by the following claim: Sports and recreation tourism, as the most important part of the tourist offer (Standeven \& Knop, 1999; Hayward, 2001; Weed \& Bull, 2004; Weed, 2008; Vujko \& Plavša, 2013; Vujko \& Plavša, 2014), present a primary characteristic and one of the main functions of this area. The principal property of Ada Ciganlija is the presence of creative and diverse content designed for a great number of various users. As the water of the Sava Lake is warmer and cleaner than in the river, the 
Aleksandra VUJKO, Tatiana N. TRETIAKOVA, Dragana DIMITRIĆ, Marko D. PETROVIĆ, Milan RADOVANOVIĆ, Darko VUKOVIĆ

lake and the island (Ada Ciganlija peninsula) have created the conditions for mass recreation and exercise for almost all water and land sports. Sports facilities and courts at Ada are numerous and this can be shown by mentioning the most important ones: two large football pitches, six concrete pitches for football and volleyball, ten basketball courts, seven outdoor tennis courts, a hall with two indoor tennis courts, six concrete volleyball courts, two sand volleyball courts, a mini-golf and golf course, football pitch, baseball field, water polo pool, which is open to the pontoons and the referee control tower and hangar space for water sports, ski lift for skiing, a hockey ground, small courts for beach volleyball, a water soccer field, bungee jumping, artificial rocks and terrain for paintball, the ground for people with disabilities, while for the fishermen near the Sava Lake there is the Ada Safari Lake. As various sports are actively trained at Ada Ciganlija, there are two sports federations and 14 clubs here.

For over four fifths of visitors (81\%) the reasons for coming to Ada are sports and recreation (Plavša \& Dražić, 2012). The total number of tourists who visited the checkpoint TIC Ada Ciganlija during observed period (July - August 2015), was 4622 (Table 3), out of which 3266 are the residents of Belgrade (about three-fourths), 156 tourists are from the region and 1200 are foreign tourists (about a quarter). These data confirmed the hypothesis 3 . The average number of informed tourists' weekly is 385 , which makes 55 tourists a day. From the first to the eighth week, the number of tourists was constantly growing, and from the eighth to twelfth week it declined.

Table 3. Total number of tourists per week

Data source: The report of the Tourist Organization of Belgrade

\begin{tabular}{|c|c|}
\hline Week & Number of tourists \\
\hline $1^{\text {st }}$ week & 252 \\
\hline $2^{\text {nd }}$ week & 338 \\
\hline $3^{\text {rd }}$ week & 346 \\
\hline $4^{\text {th }}$ week & 348 \\
\hline $5^{\text {th }}$ week & 453 \\
\hline $6^{\text {th }}$ week & 424 \\
\hline $7^{\text {th }}$ week & 465 \\
\hline $8^{\text {th }}$ week & 520 \\
\hline $9^{\text {th }}$ week & 429 \\
\hline $10^{\text {th }}$ week & 412 \\
\hline $11^{\text {th }}$ week & 333 \\
\hline $12^{\text {th }}$ week & 302 \\
\hline The total number of tourists & 4622 \\
\hline
\end{tabular}

In the seventh week which lasted from August $8^{\text {th }}$ to August $14^{\text {th }}$ of the year 2015, the last day of the week, August $14^{\text {th }}$, which was Sunday, was said to have a record number of 203 tourists in just one day. In the week, lasting from August 15 th to August 21 $1^{\text {st }}$ of the year 2015, it was informed that there was the largest number of 520 tourists for the whole week. The total number of informed tourists who turned against TIC is 4622; out of which 3266 are the residents of Belgrade (about three-fourths), 156 tourists are from the region and 1200 are foreign tourists (about a quarter). These data confirmed the hypothesis 3. The largest number of visitors at the checkpoint TIC is from Belgrade, but the presence of the tourists from other cities in Serbia was recorded, too. However, in the first, fifth, sixth, ninth, eleventh and twelfth week, domestic tourists were recorded, but not their individual arrival from a place of birth outside Belgrade. The reason is that one of tourist clerks recorded only the total number of domestic tourists, but not their number and the origin outside of Belgrade. 
Demographic Monitoring and Forecasting

Tourists' Arrivals as a Means of Overcoming Seasonality

Table 4. The total number of domestic visitors per week (Belgrade and the rest of Serbia)

Data source: The report of the Tourist Organization of Belgrade

\begin{tabular}{|l|c|}
\hline \multicolumn{1}{|c|}{ Week } & Number of domestic visitors \\
\hline $1^{\text {st }}$ week & 184 \\
\hline $2^{\text {nd }}$ week & 260 \\
\hline $3^{\text {rd }}$ week & 253 \\
\hline $4^{\text {th }}$ week & 242 \\
\hline $5^{\text {th }}$ week & 285 \\
\hline $6^{\text {th }}$ week & 291 \\
\hline $7^{\text {th }}$ week & 300 \\
\hline $8^{\text {th }}$ week & 330 \\
\hline $9^{\text {th }}$ week & 302 \\
\hline $10^{\text {th }}$ week & 311 \\
\hline $11^{\text {th }}$ week & 268 \\
\hline $12^{\text {th }}$ week & 240 \\
\hline The total number of visitors & 3266 \\
\hline
\end{tabular}

The total number of residents of Belgrade and domestic visitors who were informed at the desk of TIC, make $70.66 \%$ of the total mass of tourists or 3266 tourists (Table 4). The identified number of tourists in the first week was actually 1184. The reason for such a large number of tourists was that one of the tourist clerks distributed leaflets for the event "Ships Carnival" which was held in Belgrade, and thus a significant number of tourists was informed about this event. If we take into account that this was the first week of existence of checkpoint TIC it's not a big mistake to take into consideration that at the checkpoint there were about 184 tourists who were looking for some information. Although the registered number and origin of tourists outside Belgrade is relatively small it is important to know that they were looking for information at the desk of TIC. Of course, it was impossible to record all the tourists if they themselves did not report where they had come from so that a significant number of domestic tourists merged with the visitors from Belgrade. Some of these tourists were in Belgrade as guests, and the others in a one-day visit. The largest number of tourists at the desk of TIC at Ada Ciganlija, who were noted down and weren 't from Belgrade, were from Vojvodina: 11 of them from Subotica; 7 of them from both Novi Sad and Smederevo; 4 from each of the following towns: Pančevo, Niš, Bor, Zaječar, Kruševac and Valjevo, while the tourists from other cities were there in a lesser extent (Table 5 and 6).

Table 5. The number of tourists from the rest of Serbia per week Data source: The report of the Tourist Organization of Belgrade

\begin{tabular}{|c|c|c|}
\hline Week & Number of domestic tourists & The total number of tourists \\
\hline $1^{\text {st }}$ week & Not counted & 1 \\
\hline $2^{\text {nd }}$ week & Bor 2, Banja Koviljača 1, Loznica 1, Kragujevac 1 & 5 \\
\hline $3^{\text {rd }}$ week & Subotica 4, Zaječar 4, Novi Sad 3, Kragujevac 1 & 12 \\
\hline $4^{\text {th }}$ week & Kruševac 4, Pančevo 2, Niš 2, Pirot 1 & 9 \\
\hline $5^{\text {th }}$ week & Not counted & / \\
\hline $6^{\text {th }}$ week & Sombor, Novi Sad, Pančevo, Kruševac, Niš & / \\
\hline $7^{\text {th }}$ week & Subotica 7, Sombor 2, Pančevo 2, Ivanjica 1, Šabac 1 & 13 \\
\hline $8^{\text {th }}$ week & Valjevo 4, Novi Sad 4, Smederevo 4, Trstenik 2, Bor 2, Niš 1 & 17 \\
\hline $9^{\text {th }}$ week & Not counted & / \\
\hline $10^{\text {th }}$ week & Smederevo 3 , Niš 1 & 4 \\
\hline $11^{\text {th }}$ week & Not counted & 1 \\
\hline $12^{\text {th }}$ week & Not counted & 1 \\
\hline & The total number of tourists & 60 \\
\hline
\end{tabular}


Aleksandra VUJKO, Tatiana N. TRETIAKOVA, Dragana DIMITRIĆ, Marko D. PETROVIĆ, Milan RADOVANOVIĆ, Darko VUKOVIĆ

Table 6. The registered cumulative information about tourists from the rest of Serbia Data source: The report of the Tourist Organization of Belgrade

\begin{tabular}{|l|c|l|c|c|c|}
\hline \multicolumn{1}{|c|}{ Town } & Number of tourists & \multicolumn{1}{c|}{ Town } & Number of tourists & Town & Number of tourists \\
\hline Bor & 4 & Novi Sad & 7 & Ivanjica & 1 \\
\hline Banja Koviljača & 1 & Kruševac & 4 & Sabac & 1 \\
\hline Loznica & 1 & Pančevo & 4 & Valjevo & 4 \\
\hline Kragujevac & 2 & Niš & 4 & Trstenik & 2 \\
\hline Subotica & 11 & Pirot & 1 & Smederevo & 7 \\
\hline Zaječar & 4 & Sombor & 2 & & 60 \\
\hline \multicolumn{7}{|l|}{ The total number of tourists } & \multicolumn{5}{|l}{} \\
\hline
\end{tabular}

Of all the tourists registered at the checkpoint of TIC, the tourists from the region, from the former Yugoslav republics, represent only 3.37\% or 156 tourists. However, some of the tourists merged with domestic tourists, since they themselves did not report where they had come from. A number of registered tourists from the region came to visit someone in Belgrade or Serbia, and the other ones were on a tourist trip. Of the total number of the tourists from the region and the former Yugoslav republics at the checkpoint TIC, the most numerous were the tourists from Slovenia (32), then from Croatia (23), from Bosnia and Herzegovina (13), Macedonia (9), and the fewest tourists were from Montenegro (2). The total number of the tourists from the region and the former Yugoslav republics at the point TIC, who were being informed, was 79. The real number of tourists from the region and the former Yugoslav republics, who were being informed at the point TIC, was 156 tourists in twelve weeks. This difference occurred because one of the tourist clerks had not separately classified tourists by country of origin but had merged them all in the total number of tourists from the region. In the total mass of tourists at the checkpoint TIC of Tourist Organization of Belgrade, foreign tourists occupy a significant number or a quarter of all the tourists being informed. This information indicates that during observed period, at Ada Ciganlija, there were many more foreign tourists than tourists from the region (tourists from the former Yugoslav republics).

Table 7. Number of foreign tourists per week

Data source: The report of the Tourist Organization of Belgrade

\begin{tabular}{|l|l|l|l|}
\hline Week & Number of tourists & Week & Number of tourists \\
\hline $1^{\text {st }}$ week & 63 & $7^{\text {th }}$ week & 141 \\
\hline $2^{\text {nd }}$ week & 64 & $8^{\text {th }}$ week & 183 \\
\hline $3^{\text {rd }}$ week & 87 & $9^{\text {th }}$ week & 100 \\
\hline $4^{\text {th }}$ week & 93 & $10^{\text {th }}$ week & 93 \\
\hline $5^{\text {th }}$ week & 147 & $11^{\text {th }}$ week & 56 \\
\hline $6^{\text {th }}$ week & 122 & $12^{\text {th }}$ week & 51 \\
\hline \multicolumn{2}{|l}{ Total number of tourists } & 1200 \\
\hline
\end{tabular}

According to the report of the Tourist Organization of Belgrade, the total number of foreign tourists being informed at the checkpoint TIC was $25.96 \%$ or 1200 tourists (Table 7). From the table 4 it can be seen that the number of foreign tourists is constantly growing from the first to the fifth week, that it varies from the fifth to the eighth week, but still remains high, and from the ninth to the twelfth week it significantly decreases. The highest number of foreign tourists was registered during the eighth week, 183 of them. The first two and last two weeks registered the lowest number of foreign tourists. The most numerous (Table 5), were the tourists from Great Britain (216), then there were quite a lot of them from Germany (71) and France (57), while the tourists from Russia, 
Italy, Spain and Sweden were of almost equal number - slightly more than 30 tourists. At the checkpoint TIC, there was a significant number of tourists from overseas countries, as well, USA (23) and Australia (19). There were 10 tourists from China (Table 8).

Table 8. The registered number of tourists and their origin Data source: The report of the Tourist Organization of Belgrade

\begin{tabular}{|c|c|c|}
\hline & Country where tourists come from & Number of foreign tourists \\
\hline 1. & Great Britain & 216 \\
\hline 2. & Germany & 71 \\
\hline 3. & France & 57 \\
\hline 4. & Russia & 36 \\
\hline 5. & Italy & 33 \\
\hline 6. & Spain & 32 \\
\hline 7. & Sweden & 31 \\
\hline 8. & USA & 23 \\
\hline 9. & Austria & 20 \\
\hline 10. & Australia & 19 \\
\hline 11. & Greece & 18 \\
\hline 12. & Ireland & 16 \\
\hline 13. & Czech & 15 \\
\hline 14. & Netherlands & 14 \\
\hline 15. & Turkey & 13 \\
\hline 16. & Switzerland & 12 \\
\hline 17. & Belgium & 11 \\
\hline 18. & China & 10 \\
\hline 19. & Canada & 8 \\
\hline 20. & Norway & 7 \\
\hline 21. & Slovakia & 7 \\
\hline 22. & Finland & 6 \\
\hline 23. & Syria & 5 \\
\hline 24. & Israel & 5 \\
\hline 25. & New Zealand & 4 \\
\hline 26. & Romania & 4 \\
\hline 27. & Argentina & 3 \\
\hline 28. & India & 2 \\
\hline 29. & Portugal & 2 \\
\hline 30. & Hungary & 2 \\
\hline 31. & Bulgaria & 2 \\
\hline 32. & Poland & 2 \\
\hline 33. & Iraq & 1 \\
\hline 34. & Island & 1 \\
\hline 35. & Pakistan & 1 \\
\hline 36. & Denmark & 1 \\
\hline 37. & Ukraine & 1 \\
\hline 38. & Ecuador & 1 \\
\hline & Total number of tourists & 712 \\
\hline
\end{tabular}

\section{CONCLUSION}

The most important urban tourist destinations in Serbia are the main administrative centers, Belgrade, Novi Sad and Niš. Thanks to the favorable tourist and geographical position, natural values in the area, a rich cultural and historical heritage 
and a solid material basis, these urban centers develop various forms of tourist movements. Therefore, it is necessary to make the analysis of tourist turnover, in order to highlight the main directions of tourism development (Cavus \& Tanrisevdi, 2002; Andriotis \& Vaughan, 2003; Harrill, 2004; Byrd, 2007; Deng et al., 2014).

The residents of Belgrade and domestic tourists represented about 70 per cent of all the tourists in Ada Ciganlija recreational center, the tourists from the region (from the former Yugoslav republics) represented more than 3 percent, while there were about 25 percent of foreign tourists. As for the domestic tourists at Ada Ciganlija, most of them were the residents of Belgrade, although residents from other cities in Serbia were registered, as well. Tourists from Slovenia and Croatia were the most numerous tourists from the region, while the most numerous foreign tourists were the ones from the United Kingdom. Since the foreign tourists represented a quarter of all the tourists, it indicates that there is a significant presence of foreign tourists at Ada Ciganlija (the Sava Lake), but it also points to the need of long-term planning (Latkova \& Vogt, 2012; Tuzunkan, 2018) of marketing activities for this area so that it would become one of the first planned landscapes to be visited by foreign tourists (Harvey et al., 1995; Jurowski et al., 1997; Lindberg \& Johnson, 1997; Mason \& Cheyne, 2000; Teye et al., 2002; Nunkoo \& Garsoy, 2012; Sharma \& Gursoy, 2015; Sinclair-Maragh et al., 2015), not only in summer, but during other seasons, as well, which would have a positive effect on the economic growth plan (Dieke, 1989; Ap, 1992; Lankford \& Howard, 1994; Gursoy et al., 2002; Deery et al., 2012).

Besides economic effect, Ada Ciganlija, as any other picnic and recreational area (Fisher \& Arnold, 1994; Haralambopoulos \& Pizam, 1996), has a significant value regarding the health (Plavša et al., 2014), of the population that visits it. Further expansion of tourism facilities and better availability of information, as is the creating of the map of Ada, with all the existing facilities, as well as the existence of a checkpoint information would raise the quality of service and even greater attendance would be achieved (Long \& Kayat; 2011; Wang, 2013). The main finding of the paper is that, in general, the prediction intervals from the ARIMA model generate prediction intervals with desirable statistical properties, at least in the context of tourism forecasting.

Acknowledgments: The research was supported by Ministry of Education, Science and Technological Development, Republic of Serbia (Grant III 47007) and by the Act 211 Government of the Russian Federation, contract No. 02. A03.21.0011.

\section{REFERENCES}

Aliaskarov, D.T., Beisenova, A.S., Irkitbaev, S.N., Atasoy, E., \& Wiskulski, T. (2017). Modern changes in Zhezkazgan city: Positive and negative factors of tourism development (Kazakhstan). GeoJournal of Tourism and Geosites, vol. 20, no. 2, p. 243-253.

Allen, L.R., Hafer, H.R., Long, P.T., \& Perdue, R.R. (1993). Rural residents' attitudes toward recreation and tourism development. Journal of Travel Research, vol. 31, no. 4, p. 27-33.

Andereck, K., \& Nyaupane, G. (2011). Exploring the nature of tourism and quality of life perceptions among residents. Journal of Travel Research, vol. 50, no. 3, p. 248-260.

Andereck, K.L., Valentine, K.M., Vogt, C.A., \& Knopf, R.C. (2007). A cross-cultural analysis of tourism and quality of life perceptions. Journal of Sustainable Tourism, vol. 15, no. 5, p. 483-502.

Andriotis, K., \& Vaughan, R.D. (2003). Urban residents' attitudes towards tourism development: The case of Crete. Current Issues in Tourism, vol. 42, no. 2, p. 172-185.

Ap, J., (1992). Residents' perceptions of tourism impacts, Annals of Tourism Research, vol. 19, p. 665-690.

Brougham, J., \& Butler, R. (1981). A segmentation analysis of resident. European Journal of Tourism Research, vol. 6 , no. 2, p. 170-182.

Blake, A., Sinclair, M.T., \& Campos Soria, J.A. (2006). Tourism productivity: Evidence from the United Kingdom. Annals of Tourism Research, vol. 33, no. 4, p.1099-1120. 
Byrd, E.T. (2007). Stakeholders in sustainable tourism development and their roles: Applying stakeholder theory to sustainable tourism development. Tourism Review, vol. 62, no. 2, p. 6-13.

Canizares, S.M.S., Canalejo, A.M.C., \& Tabales, J.M.N. (2016). Stakeholders' perceptions of tourism development in Cape Verde, Africa. Current Issues in Tourism, vol. 19, no. 10, p. 966-980.

Cavus, S., \& Tanrisevdi, A. (2002). Residents' attitudes towards tourism development: A case study in Kusadasi, Turkey. Tourism Analysis, vol. 7, no. 3-4, p. 259-269.

Chen, J.S. (2000). An investigation of urban tourism residents' loyalty of tourism. Journal of Travel and Tourism Research, vol. 24, no. 1, p. 5-19.

Chen, J., \& Hsu, C. (2002). Measurement of Korean tourists' perceived images of overseas destinations. Journal of Travel Research, vol. 38, p. 411-416.

Chibaya, T. (2013). From 'Zimbabwe Africa's Paradise' to 'Zimbabwe a World of Wonders': Benefits and challenges of rebranding Zimbabwe as a tourist destination. Developing Country Studies, vol. 3, no. 5, p. 84-91.

Chingarande, A. (2014). Can the tourism sector steer the Zimbabwe Agenda for Sustainable Socio-Economic Transformation (ZIMASSET)? International Journal of Social Relevance and Concern, vol. 2, no. 5, p. 25 -29.

Choi, H.C., \& Murray, I. (2010). Residents' attitudes towards sustainable community tourism. Journal of Sustainable Tourism, vol. 18, no. 8, p. 575-594.

Deery, M., Jago, L., \& Fredline, L. (2012). Rethinking social impacts of tourism research: A new research agenda. Tourism Management, vol. 33, p. 64-73.

Deng, J., McGill, D., Arbogast, D., \& Maumbe, K. (2016). Stakeholders' perceptions of tourism development in Appalachian Forest Heritage Area. Tourism Review International, vol. 20, p. 235-253.

Deng, J., Arbogast, D., \& Selin, S. (2011). Community-based tourism planning: An application of the APPA approach to Anstead. West Virginia, Tourism Analysis, vol. 16, no. 5, p. 601-615.

Dieke, P. (1989). Fundamentals of tourism development: A Third World perspective. Hospitality Education \& Research Journal, vol. 13, no. 2, p. 7-22.

Dogan, H.Z. (1989). Forms of adjustment: Socio-cultural impacts of tourism. Annals of Tourism Research, vol. 16 , no. 2, 216-236.

Dwyer, L., Mellor, R., Livaic, Z., Edwards, D., \& Kim, C.W. (2004). Attributes of destination competitiveness: A factor analysis. Tourism Analysis, vol. 9, p. 91-102.

Dwyer, L., \& Kim, C. (2003), Destination competitiveness: Determinants and indicators, Current Issues in Tourism, 6, pp. 369-413.

Fischer, E., \& Arnold, S.J. (1994). Sex, gender identity, gender role attitude, and consumer behavior. Psychology and Marketing, vol. 11, no. 2, p. 163-182.

Gursoy, D., Jurowski, C., \& Uysal, M. (2002). Resident attitudes: A structural modelling approach. Annals of Tourism Research, vol. 29, p. 79-105.

Gounopoulos, D., Petmezas, D., \& Santamaria, D. (2012). Forecasting tourist arrivals in Greece and the impact of macroeconomic shocks from the countries of tourists' origin. Annals of Tourism Research, 39 (2), p. 641-666.

Hayward, P. (2001). Leisure and Tourism, Heinemann GNVQ Intermediate, Heineman, Oxford.

Haralambopoulos, N., \& Pizam, A. (1996). Perceived impacts of tourism: The case of Samos. Annals of Tourism Research, vol. 23, no. 3, 423-433. Harrill, R. (2004). Residents' attitudes toward tourism development: A literature review with implications for tourism planning. Journal of Planning Literature, vol. 18, no. 3, p. 1-16.

Harvey, M.J., Hunt, J., \& Harris, C.C. Jr. (1995). Gender and community tourism dependency level. Annals of Tourism Research, vol. 22, no. 2, 349-366.

Jarque, C., \& Bera, A. (1987). A test of normality of observations and regression Residuals. International Statistical Review, vol. 55, no. 2, p.163-172.

Jurowski, C., Uysal, M., \& Williams, D.R. (1997). A theoretical analysis of host community resident reactions to tourism. Journal of Travel Research, vol. 36, no. 3, p. 3-11.

Lankford, S.V., \& Howard, D.R. (1994). Developing a tourism impact attitude scale. Annals of Tourism Research, vol. 21, no. 1, p. 121-139.

Latkova, P., \& Vogt, C.A. (2012). Residents' attitudes toward existing and future tourism development in rural communities. Journal of Travel Research, vol. 51, no. 1, p. 50- 67.

Lew, A., \& McKercher, B. (2006). Modeling Tourists Movement - A Local Destination Analysis. Annals of Tourism Research, vol. 33, no. 2, p. 403-423.

Lee, C. C., \& Chang, C. P. (2008). Tourism Development and Economic Growth: A Closer Look at Panels, Tourism Management, vol. 29, p.180-192.

Lindberg, K., \& Johnson, R.L. (1997). Modeling resident attitudes toward tourism. Annals of Tourism Research, vol. 21, p. 402-424.

Long, P.H., \& Kayat, K. (2011). Residents' perceptions of tourism impact and their support for tourism development: The case study of Cuc Phuong National Park, Ninh Binh province, Vietnam. European Journal of Tourism Research, vol. 4, no. 2, p. 123-146.

Marković, S., Perić, M., Mijatov, M., Doljak, D., \& Žolna, M. (2017). Application of Tourist Function Indicators in Tourism Development. Journal of the Geographical Institute “Jovan Cvijić” SASA, vol. 67, no. 2, p. 163-178. 


\section{Aleksandra VUJKO, Tatiana N. TRETIAKOVA, Dragana DIMITRIĆ,}

Marko D. PETROVIĆ, Milan RADOVANOVIĆ, Darko VUKOVIĆ

Mason, P., \& Cheyne, J. (2000). Residents' attitudes to proposed tourism development. Annals of Tourism Research, vol. 27, no. 2, p. 391-411.

Mhlanga, O., Hattingh, Z., \& Moolman, H.J. (2015). Influence of demographic variables on customers' experiences in formal full-service restaurants in Port Elizabeth. South Africa, Tourism, vol. 63, no. 2, p. 143-160.

Nunkoo, R., \& Gursoy, D. (2012). Residents' support for tourism - An identity perspective. Annals of Tourism Research, vol. 39, no. 1, p. 243-268.

Nunkoo, R., \& Smith, S. L. J. (2013). Political economy of tourism: Trust in government actors, political support, and their determinants. Tourism Management, vol. 36, p.120-132.

Papić-Blagojević, N., Vujko, A., \& Gajić, T. (2016). Comparative analysis of exponential smoothing models to tourists' arrivals in Serbia. Economic of agriculture, vol. 63, no. 3, p.835-847.

Petrović, M.D., Blešić, I., Ivolga, A., \& Vujko, A. (2016). Agritourism Impact Toward Locals' Attitudes - An Evidence from Vojvodina Province (Serbia). Journal of the Geographical Institute "Jovan Cvijić" SASA, vol. 66, no. 1, p. 105-123.

Plavša, J., \& Dražić, Z. (2012). The views of visitors on sports and recreational activities on the Sava river. Proceedings no. 41, Faculty of Science Department of Geography, Tourism and Hotel Novi Sad, p.285-296.

Plavša, J., Ostojić, N., \& Vujko, A. (2014). Students' attitude and effects of sport and recreational tourism on success in schools. Geojournal for Tourism and Geosites, vol. 2, no. 14, p. 143-150.

Schwarz, G. E. (1978). Estimating the dimension of a model. Annals of Statistics, vol. 6, no. 2, p.461-464.

Sekaran, U., \& Bougie, R. (2013). Research methods for business: A skill building approach. Wiley, New York, p. 148.

Sharma, B., \& Gursoy, D. (2015). An examination of changes in residents' perceptions of tourism impacts over time: The impact of residents' socio-demographic characteristics. Asia Pacific Journal of Tourism Research, vol. 20, no. 12, p. 1332-1352.

Sinclair-Maragh, G. (2017). Demographic analysis of residents' support for tourism development in Jamaica. Journal of Destination Marketing \& Management, vol. 6, p. 5-12.

Sinclair-Maragh, G., Gursoy, D., \& Vieregge, M. (2015). Residents' perceptions toward tourism development: A factor-cluster approach. Journal of Destination Marketing Management, vol. 4, no. 1, p. 36-45.

Standeven, J., \& Knop, P. (1999). Sport Tourism, Human Kinetics, USA

Sudheer, G., \& Suseelatha, A. (2015). Short term load forecasting using wavelet transform combined with Holt-Winters and weighted nearest neighbor models. International Journal of Electrical Power \& Energy Systems, vol. 64, p. 340-346.

Teye, V., Sonmez, S.F., \& Sirakaya, E. (2002). Residents' attitudes toward tourism development. Annals of Tourism Research, vol. 29, no. 3, p. 668-688.

Turanligil, F.G., \& Altintas, V. (2018). Analysis of industry perceptions and expectations of tourism students: A case study in Turkey. GeoJournal of Tourism and Geosites, vol. 21, no. 1, p.266-281. Tuzunkan, D. (2018). Undergraduate tourism students' perceptions and attitudes towards tourism industry: The case of Daejeon, South Korea. GeoJournal of Tourism and Geosites, vol. 21, no. 1, p. 103-111.

Ursache, M. (2015). Tourism - significant driver shaping a destinations heritage. Procedia - social and Behavioral Sciences, vol. 188, no. 14, p.130-137.

Van Den Bergh, J.C.J.M. (1993). A framework for modeling economy-environment-development relationships based on dynamic carrying capacity and sustainable development feedback. Environmental Resources and Economics, vol. 3, no. 4, p. 395-412.

Vujko, A., Plavša J. (2013). Possibilities of improving international cross-border cooperation through cycling „Szekelys route“, Geojournal for Tourism and Geosites, vol. 2, no. 12, p. 185-203.

Vujko, A., Gajić, T. (2014). The government policy impact on economic development of tourism. Agricultural economics, vol. 61 , no. 3 , p.789-804.

Vujko, A., Plavša, J. (2014). Evaluation of National Park Fruška Gora (Serbia) for sport and recreational Tourism. Acta geographica Slovenica, vol. 54, no. 2, p.321-334.

Vujko, A., Papić-Blagojević, N., \& Gajić, T. (2018). Applying the exponential smoothing model for forecasting tourists arrivals in Serbia - Example of Novi Sad, Belgrade and Niš. Economic of agriculture, vol.65, no. 2, p. 465-484.

Wang, S. (2013). Predicting effects of demographics and moderating power of engagement on residents' perceptions of tourism development. European Journal of Tourism Research, vol. 6, no. 2, p. 170-182.

Weed, M. (2008). Sport tourism experience. Journal of Sport and tourism, vol. 13, p. 1-4.

Weed, M., \& Bull, C. (2004). Sports tourism: participants, policy and providers, Oxford: Elsevier Butterworth Heinemann.

Whittle, P. (1951). Hypothesis Testing in Time Series Analysis, Almquist and Wicksell.

Zengeni, N., \& Zengeni, D.M.F. (2012). Visa regime policy and tourism recovery and development in Zimbabwe, International Journal of Development and Sustainability, vol. 1, no. 3, p. 1008-1025.

Submitted:

04.04.2018
Revised:

23.07.2018
Accepted and published online 25.07.2018 